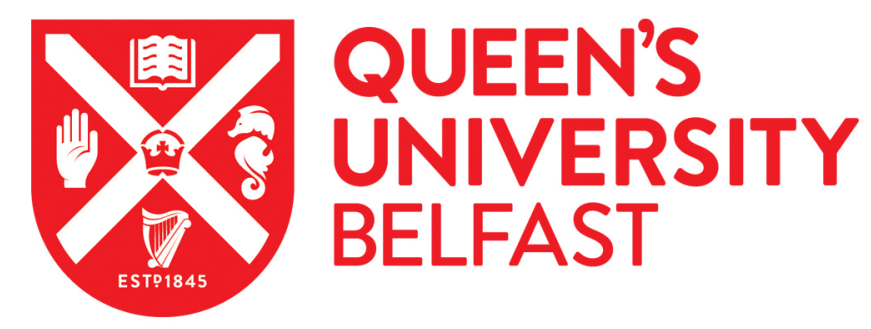

\title{
Understanding how HR systems work: the role of HR philosophy and HR processes
}

Monks, K., Kelly, G., Conway, E., Flood, P., Truss, K., \& Hannon, E. (2013). Understanding how HR systems work: the role of HR philosophy and HR processes. Human Resource Management Journal, 23(4), 379-395. https://doi.org/DOI:10.1111/J.1748-8583.2012.00207.X

\section{Published in:}

Human Resource Management Journal

\section{Document Version:}

Peer reviewed version

\section{Queen's University Belfast - Research Portal:}

Link to publication record in Queen's University Belfast Research Portal

\author{
Publisher rights \\ ( 2012 John Wiley \& Sons Ltd \\ This is the peer reviewed version of the following article: Monks, K., Kelly, G., Conway, E., Flood, P., Truss, K. and Hannon, E. (2013), \\ Understanding how HR systems work: the role of HR philosophy and HR processes. Human Resource Management Journal, 23: 379-395, \\ which has been published in final form at http://onlinelibrary.wiley.com/doi/10.1111/j.1748- \\ 8583.2012.00207.x/abstract;jsessionid=04C13570D3DF67FB03695549B97897C6.f01t04. This article may be used for non-commercial \\ purposes in accordance with Wiley Terms and Conditions for Self-Archiving

\section{General rights} \\ Copyright for the publications made accessible via the Queen's University Belfast Research Portal is retained by the author(s) and / or other \\ copyright owners and it is a condition of accessing these publications that users recognise and abide by the legal requirements associated
} with these rights.

Take down policy

The Research Portal is Queen's institutional repository that provides access to Queen's research output. Every effort has been made to ensure that content in the Research Portal does not infringe any person's rights, or applicable UK laws. If you discover content in the Research Portal that you believe breaches copyright or violates any law, please contact openaccess@qub.ac.uk. 


\title{
Understanding how HR systems work: the role of HR philosophy and HR processes
}

\author{
Kathy Monks, Gráinne Kelly, Edel Conway and Patrick Flood, Leadership, \\ Innovation and Knowledge Research Centre, Dublin City University \\ Katie Truss, Kent Business School, University of Kent \\ Enda Hannon, Kingston Business School, Kingston University \\ Human Resource Management Journal, Vol ••, no ••, 2012, pages ••-••
}

Despite the proliferation of studies of HR systems, there are still substantial gaps in our understanding of how such systems actually work. This article, by focusing on the neglected areas of HR philosophy and HR processes in the composition of HR systems, and by using a qualitative, employee-centred approach in the collection and analysis of data, provides new insights into the working of HR systems. Using data from interviews with 56 knowledge workers employed in the information and communications technology sector in Ireland and the UK, we explore employee-level reactions to two different types of HR systems. We highlight the various ways in which HR processes interact with HR practices and the different outcomes that may result, and we identify the key role of HR philosophy in HR system operation.

Contact: Kathy Monks, Leadership, Innovation and Knowledge Research Centre, Dublin City University, Dublin 9, Ireland. Email: kathy.monks@dcu.ie

\section{INTRODUCTION}

$\mathbf{W}$ hile there is now a great deal known about the nature of HR systems, there are still gaps in our understanding of how such systems actually work (Becker and Gerhart, 1996; Chadwick, 2010; Boxall et al., 2011; Jiang et al., 2012). Such gaps are perhaps not surprising. Much of the HR system research to date has been based on firm-level quantitative approaches that focus on HR practices (Boselie et al., 2005; Guest, 2011) rather than other aspects of the HR system. In order to extend understanding of how HR systems work, we follow Bowen and Ostroff (2004) in concentrating on process: 'the features of an HR system that send signals to employees that allow them to understand the desired and appropriate responses and form a collective sense of what is expected' (p. 204).

In our attention to process, we first of all examine features of the HR system that have been identified as neglected in research to date, notably HR philosophy (Lepak and Snell, 2002; Lepak et al., 2007) and HR processes (Boxall and Macky, 2009). Second, we focus on the ways in which employees interact with and interpret different types of HR systems. In concentrating on employee attitudes and behaviours, we are brought to the 'realm of the black box', and encounter the 'murky chain of links between HR goals and performance outcomes' (Boxall et al., 2011: 1508). Using qualitative data from interviews with 56 knowledge workers employed in the information and communications technology (ICT) sector in Ireland and the UK, we explore employee-level reactions to two different types of HR systems: commitment-based and productivity-based (Lepak and Snell, 2002), thus encompassing both 'high' and 'low' road approaches to the management of human resources (Osterman, 1995; Orlitzky and Frenkel, 2005). Our choice of qualitative research enabled us to address "'how" questions - rather than "how many"' - and proved invaluable in 
'understanding the world from the perspective of those studied (i.e. informants); and for examining and articulating processes' (Pratt, 2009: 856).

The article begins by unpacking the components of HR systems before describing the research methodology and the findings. We discuss our findings in the light of the insights we obtain into how HR systems work before considering the implications for practice.

\section{THE COMPONENTS OF HR SYSTEMS}

There are difficulties in finding an agreed definition of the concept of HR systems with research studies indicating variations in both their composition as well as with the internal relationships among their components (Chadwick, 2010; Jiang et al., 2012). There is general acceptance that HR systems comprise a number of different levels (Becker and Gerhart, 1996; Boxall and Macky, 2009; Jiang et al., 2012); that, at a minimum, they consist of HR policies, practices and processes (Schuler, 1992; Monks and McMackin, 2001; Kepes and Delery, 2007); and that they can be linked to outcomes at employee and organisational levels (Nishii et al., 2008; Boxall et al., 2011). Theoretical work on the 'strength' of the HR system (Bowen and Ostroff, 2004) suggests that this 'strength' is a 'linking mechanism that builds shared, collective perceptions, attitudes and behaviours among employees' (Bowen and Ostroff, 2004: 206). There are, though, suggestions that the definition of the construct of HR systems is incomplete (Boselie et al., 2005; Chadwick, 2010), and we therefore consider, in particular, features that have been identified as neglected to date, notably HR philosophy and HR processes (Becker and Gerhart, 1996; Lepak and Snell, 2002; Lepak et al., 2007; Boxall and Macky, 2009).

\section{HR philosophy}

HRM system philosophies have been described as 'the guiding principles that identify and characterise the value and treatment of employees covered within a particular HRM system' (Kepes and Delery, 2007: 390). This notion of 'guiding principles' echoes Becker and Gerhart (1996: 786), who point out that it is at this level within the HR system that effects are 'generalizable or universal'. Schuler (1992: 21) is more emphatic in his definition, suggesting that an HR philosophy is 'a statement of how the organisation regards its human resources, what role the resources play in the overall success of the business and how they are to be treated and managed'. The impact of HR philosophy is confirmed by Godard and Delaney (2000) who found that the value placed on human capital by those in decision-making positions within organisations will affect the types of HR systems that are chosen and how they are used. Boxall and Macky (2009: 7) take the importance of the role of HR philosophy in HR system design a stage further by suggesting that 'we get closer to describing HR systems in meaningful terms when we identify the principal themes that underpin them: in other words, when we describe the major philosophies that management is trying to pursue'. Lepak et al. (2007: 241), from their research in 402 establishments in the US, revealed the importance of HR philosophy in determining how high investment human resource (HIHR) systems were fashioned for both core and support employees. However, they also point out that HR philosophy has not 'occupied a dominant focus within previous HRM studies' and suggest that there is a need for more research that examines its role as a 'contextual variable that might influence the HIHR performance relationship' (p. 241). Similarly, Lepak and Snell (2002), from a firm-level study in the US, suggest a need for research to examine the role of firm-level HR philosophy to better understand how workers in different employment modes are managed. 


\section{HR policies, practices and processes}

Policies, practices and processes are distinct elements of an HR system, occupying different levels (Becker and Gerhart, 1996). Kepes and Delery (2007: 390) suggest that HR policies serve as 'guidelines and benchmarks for specific HR activities' and that they 'reflect what an organisation is trying to achieve, not how it will achieve its goals'. In contrast, HR practices 'identify broad HRM activities and techniques to ensure the actual implementation of the HRM policies'. It is perhaps at the practice level of the HR system that most research has been undertaken to date, particularly in regard to the role of HR practices in high-performance work systems. A central issue in this debate is the ways in which the HR practices might complement or fit with one another, and the additive and synergistic effects (both positive and negative) that might accrue (Becker et al., 1997; Kepes and Delery, 2007).

HR processes have been viewed as denoting 'detailed explanations of how the HRM practices are executed', and it is suggested that they 'more directly affect employees, their behaviours and attitudes than do policies' (Kepes and Delery, 2007: 390-391). Early work by Lawler (1986) on high-involvement work practices suggests that such practices operate through processes that involve the enhancement of skills and knowledge, the sharing of information and power, and the rewarding of performance. However, despite the importance of processes within HRM systems, relatively little research has been undertaken into their role, perhaps because they are the least tangible aspect of the HR system, and cannot easily be identified and measured in the same way as HR practices. They are, therefore, not easily amenable to the quantitative approaches that have been used in much of the HRM system research. Yet Boxall and Macky (2009: 7) suggest that 'to make genuine theoretical progress, researchers must therefore go beyond the list of practices and seek to identify the processes and mediating variables which a set of practices is supposed to influence (Becker and Gerhart, 1996)'.

\section{Outcomes: employee experiences of HR systems}

Research into the HRM and performance linkage has identified employee experiences of and reactions to $\mathrm{HR}$ practices as having a potentially important mediating role in the HRM-performance linkage (Nishii et al., 2008; Kehoe and Wright, forthcoming). Evidence suggests that experiences of HR practices differ according to particular employee groups (Kinnie et al., 2005) and that there may be different outcomes for employees. Positive employee outcomes that have been reported include job satisfaction (Nishii et al., 2008), trust in management (Macky and Boxall, 2007) and intention to remain with the organisation (Kehoe and Wright, forthcoming). At the same time, studies have also reported negative outcomes for employees from exposure to high-performance work practices that include work intensification, stress and job strain (Ramsay et al., 2000; Godard, 2004).

\section{Configuring HR systems: the case of knowledge workers}

As well as choosing between components of HR systems, organisations may choose to configure these in different ways. They may decide to use enabling ('high-road') models or coercive ('low-road') models of HRM (Orlitzky and Frenkel, 2005: 1326). They may decide to differentiate between employee groups on the basis of each group's human capital value by using different types of HR systems to manage 'core' and 'support' employees (Lepak et al., 2007). Alternatively, they may identify different types of employment modes and match these with appropriate HR configurations (Lepak and Snell, 2002; Swart and Kinnie, 2012). The choices may be particularly complex for firms that are engaged in knowledge creation and in the management of knowledge workers. Insights into this complexity are obtained from 
research undertaken by Lepak and Snell (2002) in 148 firms in the US. They propose a model (Lepak and Snell, 1999) of the relationships between human capital characteristics and employment modes that is based on the extent to which human capital is unique and of strategic value. They identify four different employment modes (knowledge-based, job-based, contract work and alliance/partnerships) and match these to four different HR configurations: commitment, productivity, compliance and collaboration (Table 1).

Lepak and Snell (2002) found that the use of the commitment-based HR configuration was significantly greater for knowledge-based employees than for other types of workers. Yet they also found that both the productivity-based and the collaborative-based HR configurations were used in the management of knowledge-based employees. Their research findings in relation to the use of high-commitment $\mathrm{HR}$ practices in the management of knowledge workers have commonalities with other research (Swart et al., 2003; Collins and Smith, 2006). However, their findings are surprising in relation to the use of the productivity-based HR configuration for knowledge-based employees. This configuration is described as one where managers are engaged in 'hiring employees, paying them a market-based wage, focusing on their job performance and preparing for the possibility that they may leave' (p. 522). Such an approach appears at odds with much of the literature on how knowledge workers should be managed. At the same time, it resonates with the research in the Scottish ICT sector which found that training and development opportunities to enhance existing skill sets which might be expected to accompany engagement in knowledge work are not necessarily provided (Marks and Scholarios, 2007; Marks and Huzzard, 2010), suggesting that gaps may exist between the rhetoric of knowledge work and the experiences of knowledge workers.

\section{Summary}

The above review indicates that there are still gaps in our understanding of some of the core processes underpinning the ways in which HR systems work. In this article, we focus on understanding the role of HR philosophy and HR processes in the operation of HR systems by considering knowledge workers' experiences of two different types of HR systems.

\section{THE RESEARCH}

The data were gathered by two research teams in Ireland and the UK who, between January and August 2009, conducted 56 semi-structured interviews with employees in seven ICT firms. The ICT sector has been identified in both Ireland and Britain as of central importance as each country strives to become a knowledge economy, and knowledge workers within these firms have been identified as key to ensuring the innovation necessary to the sector's success [Department for Education and Skills, 2005; Expert Group on Future Skills Needs (EGFSN), 2008]. The research is part of a larger study into knowledge-intensive firms in the pharmaceutical and ICT sectors that included employee-level and industry-level surveys. A profile of the firms is provided in Table 2. Access to firms proved difficult as the study was conducted as the economic downturn, particularly in Ireland, was affecting competitiveness. As a result, many of the firms in our sample were small in size, although this small size is not untypical of the sector as a whole (EGFSN, 2008).

Interviews were requested with employees engaged in knowledge work within the organisations, as well as with HR staff and senior managers, and Table 3 shows the number of interviews in each firm. In identifying knowledge workers, we followed the categorisation used by other researchers in terms of level of education and qualifications (e.g. Janz et al., 1997; Marks and Scholarios, 2007), and the degree to which they are engaged in professional and technical 


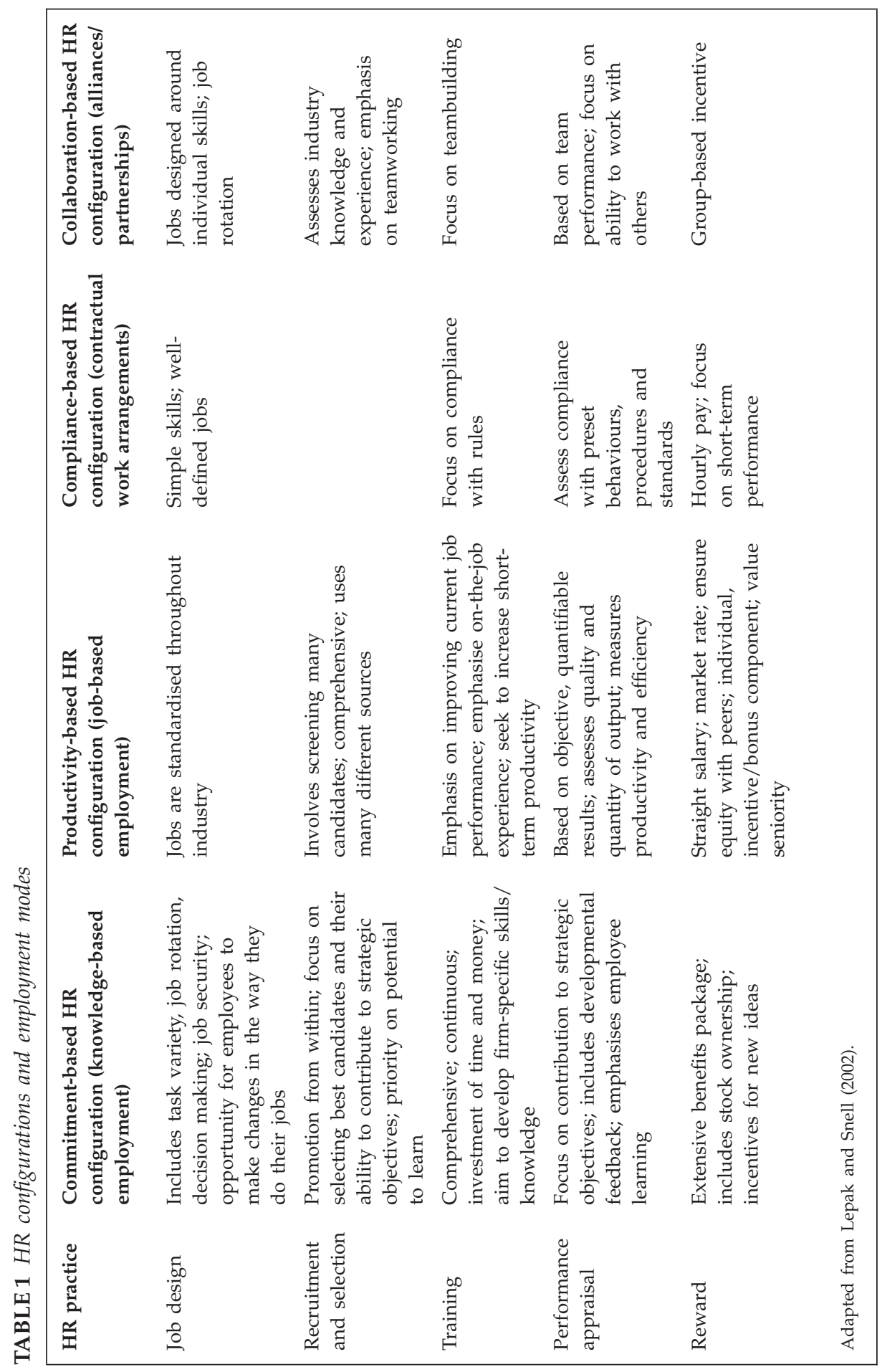

HUMAN RESOURCE MANAGEMENT JOURNAL, VOL •• NO ••, 2012 
TABLE 2 Profile of organisations

\begin{tabular}{|c|c|c|c|c|c|}
\hline Firm & $\begin{array}{l}\text { UK/ } \\
\text { Ireland }\end{array}$ & Ownership & Main business & $\begin{array}{l}\text { No. of } \\
\text { employees in } \\
\text { organisation }\end{array}$ & $\begin{array}{l}\text { No. of } \\
\text { employees } \\
\text { in firm }\end{array}$ \\
\hline ICT1 & Ireland & Indigenous & Software solutions & 90 & $\mathrm{n} / \mathrm{a}$ \\
\hline ICT2 & Ireland & Multinational & Software/management & 6,000 & 90 \\
\hline ICT3 & Ireland & Indigenous & $\begin{array}{l}\text { Communications-enabled } \\
\text { business processes }\end{array}$ & 17 & $\mathrm{n} / \mathrm{a}$ \\
\hline ICT4 & UK & Multinational & $\begin{array}{l}\text { IT systems, services and } \\
\text { products }\end{array}$ & $100,000+$ & 1,240 \\
\hline ICT5 & UK & Multinational & $\begin{array}{l}\text { Software and services } \\
\text { solutions }\end{array}$ & $100,000+$ & 57 \\
\hline ICT6 & UK & Multinational & $\begin{array}{l}\text { Electronic software } \\
\text { products }\end{array}$ & 1,750 & 200 \\
\hline ICT7 & UK & Indigenous & $\begin{array}{l}\text { Information assurance } \\
\text { solutions }\end{array}$ & 42 & $\mathrm{n} / \mathrm{a}$ \\
\hline
\end{tabular}

TABLE 3 Numbers of interviewees

\begin{tabular}{|llllllll|}
\hline & ICT1 & ICT2 & ICT3 & ICT4 & ICT5 & ICT6 & ICT7 \\
HR staff & 1 & 3 & 1 & 3 & 1 & 1 & 2 \\
Chief executive officers/managing directors & 1 & 0 & 1 & 1 & 0 & 1 & 1 \\
Knowledge workers & 4 & 6 & 5 & 5 & 7 & 7 & 5 \\
Total & 6 & 9 & 7 & 9 & 8 & 9 & 8 \\
\hline
\end{tabular}

work (e.g. Choi and Varney, 1995; Alvesson, 2001). The interviewees all held third-level qualifications and were working in a variety of different roles that included software developer, software programmer, systems architect, engineer and technical consultant. All were permanent employees, following Lepak and Snell's (2002) classification of knowledge-based employment as involving 'relationships in which firms develop and maintain a long-term commitment to full-time employees over time' (p. 525). The interviews explored employees' experiences of work and their response to HR practices. In the case of the HR staff, the interviews explored HR strategies, and the design and delivery of HR practices. Interviews with senior managers focused on business and management philosophies and strategies. In all cases, the interviews lasted between 45 and 60 minutes, and were tape-recorded and transcribed and analysed using the NVivo software package (QSR International, Doncaster, Victoria, Australia). As well as undertaking interviews, we perused company documentation, such as mission and vision statements, and business and HR strategies.

To analyse the data, we undertook three cycles of NVivo coding. Phase 1 coding was open coding and focused on identifying the broad HR configurations identifiable within the data. Phase 2 coding was hierarchical and focused on breaking down the categories into their subcategories so as to better understand the meanings embedded therein (the HR philosophies, HR policies and HR processes). Phase 3 coding consisted of analysing employees' experiences of each system.

In order to label the HR systems within these firms, we compared the HR practices utilised in our sample of firms against the checklist of HR practices used by Lepak and Snell (2002) in 
their research to construct four different HR configurations: commitment, productivity, compliance and collaboration (see Table 1). We were able to broadly match two types with our data: commitment-based and productivity-based configurations, and this led us to categorise four firms (ICT1, ICT2, ICT5, ICT7) as having productivity-based HR configurations and two (ICT3, ICT6) as having commitment-based HR configurations in the management of their knowledge workers. In ICT4, these two approaches operated in tandem but were directed at separate sections of the workforce, with its services division using a productivity-based configuration and its solutions division using a commitment-based configuration. We were not surprised to find common approaches to workforce management used in most of these firms as either the divisions in which we interviewed or the firms themselves were very small in size and employed very similar types of employees.

We describe the findings under the two headings of commitment-based and productivitybased configurations, and under each configuration describe the HR philosophies, practices and processes, and outcomes as depicted by employee attitudes and behaviours. Figure 1 shows the ways in which we linked elements of the HR philosophy to the key HR practices and the NVivo themes that supported this categorisation.

\title{
COMMITMENT-BASED HR CONFIGURATIONS
}

\section{HR philosophy}

The commitment-based configurations (ICT3, ICT6, ICT4 solutions) were underpinned by HR philosophies focused on enhancing employee capabilities. The HR manager in ICT6 explained:

\begin{abstract}
“Because we're an intellectual property business, we're about as knowledge intensive, or whatever you want to call it, as you can get in the world. So our basic HR strategy works around the model of social capital being the primary driver of innovation and of knowledge sharing and therefore of intellectual capital".
\end{abstract}

In ICT6, the building of an HR strategy around social capital comprised a number of reinforcing HR processes that included employee consultation groups, an 'open culture', a focus on engagement, a very clear definition of management roles and responsibilities with a mix of hard and soft measures, and a biannual survey on innovation. The focus of this strategy was confirmed in an interview with the chief executive officer (CEO) of this firm who stated: "we strive for innovation, creating the world's best microprocessors which comes out of having ingenious problem-solving people, making sure that employees are proud of what they create and so on".

\section{HR practices}

Job design In the firms with commitment-based HR configurations, jobs were designed to be intellectually stimulating, and to enhance autonomy and creativity. An engineering manager in ICT6 stated: "to create ideas we have to innovate. Innovation is a word that is spoken about a lot" and "that at heart we are designers. At lot of what we do is based upon experience, exploration and to some extent intuition and putting these things together to create a new solution". In the solutions division of ICT4, the chief architect explained how he tried to "understand the individual and fit around the way they like to work and the way they want to progress. I try to give as much autonomy as possible". This autonomy also extended to lower level positions, and the head of software development explained how "we basically give autonomy in terms of suggesting changes or suggesting solutions". 
FIGURE 1 NVivo themes

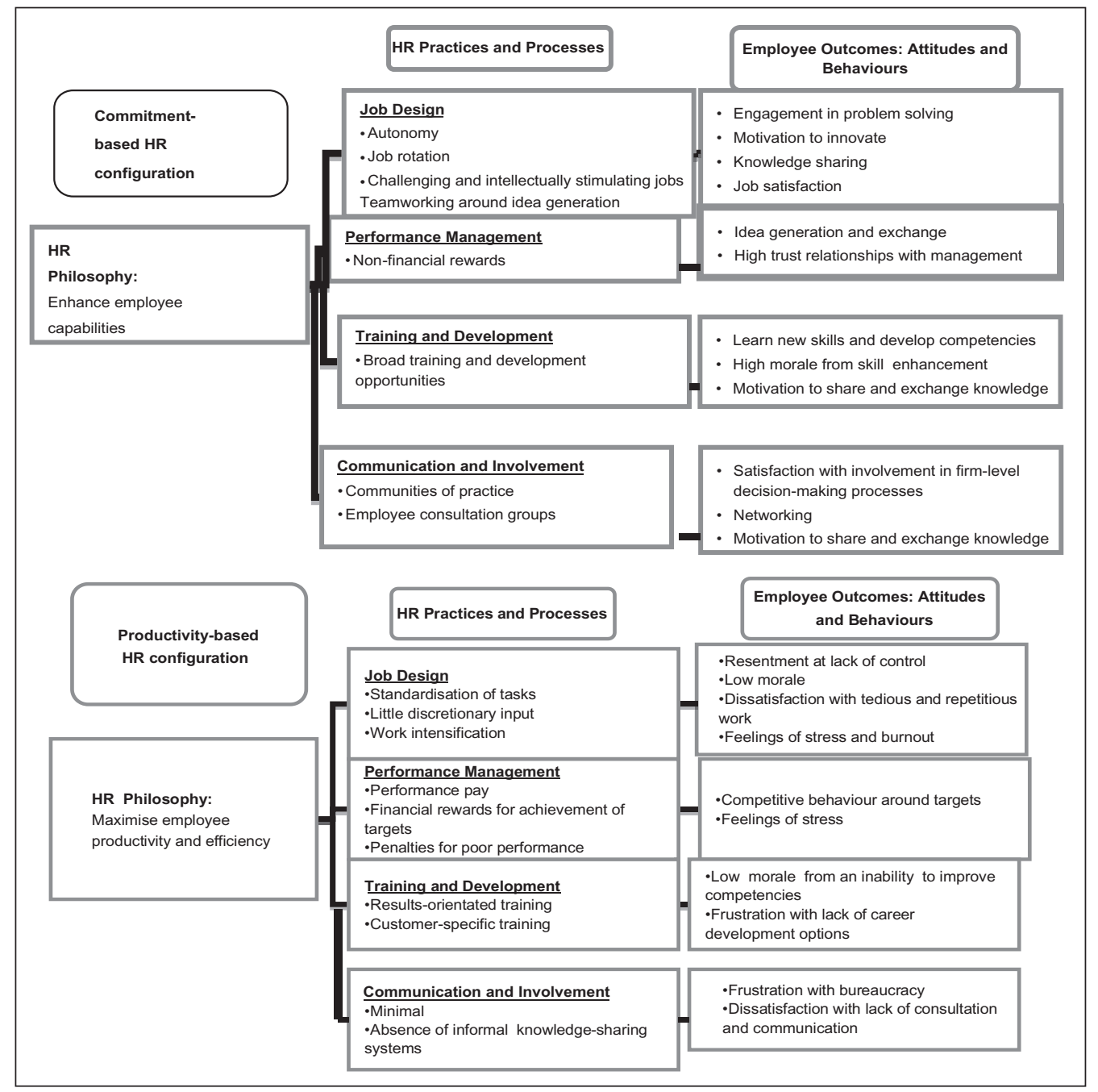

Performance management Performance management was an important practice and the processes through which it was implemented mitigated what might have been viewed as punitive elements. For example, in ICT6, the performance of managers was based on a management charter that defined the roles and responsibilities of every manager, and that had built in a set of expectations and values about leadership responsibilities. Managers were penalised financially for failure, for example, to carry out reviews with their staff. But the rationale behind this was based on "essentially putting a value on leadership and saying that there's a set of minimum standards which is the Charter and if you fall below that then it's really not acceptable, given all the training, the support and all the rest that's available" (HR Manager, ICT6). In ICT3, the focus was also on measurement, but they also aimed to "try to identify what the problem is, where the gap is, and interject accordingly - either move the work 
somewhere else or get assistance so they are capable to the level required" (Chief Technology Manager, ICT3).

Training Training and development opportunities were broad and included aspects such as graduate and talent management programmes that encompassed assessment centres and leadership forums, as well as the provision of a menu of training opportunities from which employees could choose (ICT4, Solutions Division). In ICT6, the target of training and development initiatives was the management cadre. An individualised approach to training and development was found in ICT6 where there was an emphasis on individuals acquiring additional skills from involvement in different types of projects.

\section{HR processes}

A range of reinforcing processes was used to promote the HR philosophies and practices espoused by these firms, and these processes worked across a number of HR practices to deepen and extend their impact. For example, the communication and knowledge-sharing processes were intertwined, with one seen as enhancing and extending the other. The head of solution design and development in ICT4 explained that encouraging knowledge sharing is:

\footnotetext{
"around engagement and communication more than training ... it is about trying to get people to understand why they want to do the knowledge share, what difference it makes to them more effective and how it makes the organisation more effective".
}

Specific HR processes to encourage communication included the setting up of communities of practice and the establishment of a knowledge management team to try and increase knowledge sharing across the organisation (ICT4, Solutions Division); the promotion of networking through mechanisms such as internal conferences, travel and videoconferencing (ICT6); the sharing of information through seminars or lunchtime sessions that were videoed and made available on the intranet (ICT4; ICT6); and the awarding of payments of several thousand euro for the registration of patents by individuals (ICT6). Teamworking was another process that was used in a variety of ways, not simply as a mechanism for organising work, but to encourage idea generation and problem solution, for training and developing staff, and for sharing knowledge across the organisation.

\section{Outcomes: employee attitudes and behaviours}

Employees in these firms reported outcomes that included job satisfaction, an increase in self-esteem, and the motivation to innovate and to share knowledge. Training and development opportunities enhanced employee morale and commitment, as well as increasing knowledge sharing and idea generation.

Job satisfaction arose from the autonomy that individuals were given in their jobs: in ICT3, the chief technology officer spoke of how his job satisfaction stemmed from "the freedom to express myself in my work and what I do rather than have it dictated to me". Similarly, the senior engineer in ICT6 indicated that he was "given a level of autonomy that I am able to explore the ideas... from that point of view I am very satisfied with the job". Another interviewee commented on his sense of satisfaction, which derives from "the intellectually stimulating nature of my job which involves a lot of thinking" (Service Solutions Manager, ICT4), while the head of software development in ICT3 discussed the enjoyment gained from "the challenge to discover new things" which characterised his role. The opportunity to 
innovate was also available: "innovation time is part of the role where we don't necessarily clock it on our time sheets but it is recognised as being there" (Senior Engineer, ICT4).

Training and development opportunities enhanced employee morale and commitment: "the acknowledgement by the company in the form of spending money on your development is quite a boost ... a morale boost really" (Systems Engineer, ICT3). In addition, employees were motivated to share and exchange knowledge gained from training and development so that it had a spin-off effect for other employees. An engineering manager (ICT6) explained: "you are trusted to gain from this knowledge and bring it back into the group, share it, expand it". Internal seminars also provided staff with opportunities to network and to share their knowledge, while opportunities to gain experience across a wide range of areas encouraged individuals to manage their own development.

\section{PRODUCTIVITY-BASED HR CONFIGURATIONS}

\section{HR philosophy}

In the firms with productivity-based HR configurations (ICT1, ICT2, ICT5, ICT7, ICT4 services), the HR philosophy was very much oriented towards maximising employee efficiency and productivity. The focus in these firms was, as the HR manager in ICT1 stated, "money, funds and budgets". This orientation then coloured the HR practices and processes strategies used within the firms. As the HR manager in ICT1 explained, "[w]e have a performance culture, it's what we are basically". A similar sentiment was echoed by the HR specialist in ICT2: "this year our current strategy is still on improvement and on being more efficient so what we're focusing on currently is to streamline our processes" (HR Business Partner, ICT2).

In ICT7, the CEO and the HR manager spoke about the values underpinning the business and HR strategies, while at the same time focusing on the punitive side to this philosophy: "as a business we are built around our core values and if people don't adhere to those values then they have no place in our business" (HR Manager, ICT7). This focus on performance was embedded strongly within the culture of these organisations. Their mission statements focused on elements such as 'results' and spoke about the customer rather than the employee.

\section{HR practices}

Job design In these firms, knowledge workers were often faced with repetitive and tedious work. An emphasis on standardisation, the reuse rather than invention of ideas, the lack of opportunity to take the risks core to creativity and innovation, and the need not to 'rock the boat' by introducing new ways of doing things were common themes in interviews. Creativity was very much reduced to cost effectiveness: "if your solution to an idea is to save a project an amount of money, then I think everyone would be behind you. However, if your idea is speculative and isn't related to delivery, I think you wouldn't be given much time of day for the idea" (Customer Services Architect, ICT1).

Performance management The performance management system was the key HR practice in these firms. When asked about the most important HR practice, the HR business partner in ICT2 replied: "I think it would have to be performance management" and gave a description of the process used to manage poor performance, indicating how "we highlight where they're failing and we'd have a one-to-one meeting or their manager would have a formal one-to-one meeting and this all written down and it's a formal letter". In ICT7, a distinction was made 
between poor performance that was due to a lack of skill that could be ameliorated through appropriate training and poor attitudes which were considered to be the basis for "parting company" (HR Manager, ICT7).

The emphasis on performance that emerged in the interviews with the CEOs and HR managers also emerged strongly in the interviews with employees, many of whom emphasised the monitoring of their behaviour through metric-based performance management systems that focused on the achievement of targets. The need to keep costs down was also incorporated into the performance management system, which meant that individuals were castigated for poor performance either through the denial of salary increases or in some cases in being sacked if they failed to meet the performance standards required in the initial training. Reward systems were very closely tied to performance metrics that related to output.

Training When training did take place in these firms, it tended to be very focused and targeted at specific groups or oriented to tool-sets, components or products that were specific not just to the firm but also to particular customer requirements. However, this produced skills that were so specialised that they were useless in the wider employment market, thus limiting employees' career options.

There were also penalties for failure to meet training standards, one of which might be dismissal from the workforce. As one interviewee explained:

\begin{abstract}
"You receive a two week intensive training course and you actually have to go to regional headquarters and pass a test. If you don't pass the test, they fly you back and so there is high pressure from the start" (Product Account Manager, ICT2).
\end{abstract}

In these firms, staff were expected to keep their skills up to date by accessing web-based courses. However, many respondents spoke of the fact that the pressures of work made it difficult to find time to fit training around busy work schedules.

\title{
HR processes
}

HR processes were used to enhance the effect of the individual HR practices by deepening their impact, while reinforcing the focus on productivity and efficiency. For example, teamworking was used to increase speed and efficiency. The HR manager in ICT1 described how teams were used so "that you can draw together particular knowledge groups and gather them around the product. It speeds things up big time". The sales manager in ICT2 indicated that employees were not encouraged to share ideas or problems outside their own team as this was seen as "wasting time". In regard to communications, the emphasis in these firms was very much on the operational aspects of communication, on the documentation of activities and knowledge so that databases could be established, whereas communications in the form of suggestions or new ideas tended to come well down a list of tasks that had to be undertaken and so were ignored unless they had an immediate impact on day-to-day activities or revenue. Processes were used to make things measurable. For example, bonuses were paid for making things more cost-effective (ICT1) with the use of "an additional commission structure just to incentivise them to collect crazy targets or whatever the case may be" (HR Manager, ICT1).

\section{Outcomes: employee attitudes and behaviours}

There were no positive outcomes reported by interviewees working in the organisations with productivity-based configurations. Instead, interviewees described the high stress levels caused by very pressurised work environments that were exacerbated by the competitive nature of the targets set by the performance management systems; dissatisfaction with tedious and repetitive 
jobs; frustration with the lack of opportunity for idea generation and creativity, or for participating in decision making; and the lack of opportunity to engage in training and development, leading to low levels of morale.

The pressure to perform in these firms created a very stressful work environment, with "a focus on numbers and sales targets" (Technical Analyst, ICT2) and "deadlines to fit a certain amount of work in and the requirement to work late or on weekends" (Software Developer2, ICT1). Interviewees expressed discontent with the intensive workload that was "difficult to keep on top of" (Technical Consultant, ICT5), and that because "the opportunity for downtime is actually fairly minimal it is very easy to get burnt out with a sort of relentless stream of stuff to be done" (Customer Solutions Architect, ICT4).

Interviewees indicated their dissatisfaction with the monotonous nature of their roles where "you tend to get stuck with a product because you know about them but there is no room to change projects" (Service Delivery Manager, ICT4), or there are "a lot of tedious, repetitive jobs, which take away from my time to develop properly" (Software Programmer, ICT1). There were few opportunities for creativity with the view expressed that "an idea would go into a queue with all the other work and wouldn't be given the time of day" (Technical Consultant, ICT5) unless it could "save the firm money or could speed up the process" (Service Manager, ICT4). Interviewees disliked the lack of responsibility and control that their jobs afforded and expressed resentment at the fact that work was always overseen by others (ICT4, Services Division; ICT7).

The performance management systems, as well as monitoring employee output, also encouraged competition between employees. The pressure to perform rendered it difficult for employees to find time to engage in any type of training apart from company-specific project training designed to increase their efficiency. An interviewee indicated his sense of disillusionment with the lack of competency development opportunities available to staff: "there's not a lot of development opportunities working here and it would be nice if employees could do things to improve their skills but also give them a greater sense of self-esteem really" (Application Specialist, ICT5).

\section{DISCUSSION}

We sought in our research to provide insights into the ways in which HR systems work by focusing on the features of HR systems that have been neglected in research to date. Figure 2 maps the linkages we found among HR philosophy, HR practices, HR processes, and employee attitudes and behaviours. We first consider the implications of our findings for understanding the role of HR philosophy and HR processes in the working of HR systems before discussing the research findings in regard to the ways in which employees interact with and interpret different types of HR system.

FIGURE 2 HR philosophy, practices, processes and employee outcomes

\begin{tabular}{|c|c|c|c|}
\hline $\begin{array}{l}\text { Choice of HR } \\
\text { philosophy } \longrightarrow\end{array}$ & $\begin{array}{l}\text { Choice of HR } \\
\text { practices } \\
\qquad\end{array}$ & $\begin{array}{l}\text { Employee } \\
\text { attitudes }\end{array}$ & $\begin{array}{l}\text { Employee } \\
\text { behaviours }\end{array}$ \\
\hline
\end{tabular}




\section{HR philosophy and HR processes}

In regard to HR philosophy, our findings suggest that this goes beyond the notion of 'guiding principles' that has been suggested by some writers (Becker and Gerhart, 1996; Kepes and Delery, 2007). Instead, HR philosophy is based on much more deep-seated notions of the value of human resources to an enterprise and how they should be treated (Schuler, 1992; Godard and Delaney, 2000; Boxall and Macky, 2009), and plays an important and permeating role in the operation of an HR system through its shaping of HR practices and processes that influence employee attitudes and behaviours.

Second, the research revealed that the ways in which HR processes were used in our sample of firms go beyond being simply 'detailed explanations of how the HRM practices are executed' (Kepes and Delery, 2007: 390-391). We found that HR processes may be used to uphold and reinforce the particular HR philosophy of the firm and the configuration of HR practices chosen to deliver this philosophy. In addition, it appears that there are choices for firms in the ways in which HR processes are used. For example, in the firms that had used commitment-based HR configurations, their HR philosophies of enhancing employee capabilities led them to choose a configuration of HR practices that reinforced this philosophy. These practices were then supported and reinforced by a complex and wide-ranging set of HR processes to encourage employee behaviours, such as engaging in idea generation and problem solving, knowledge sharing, and willingness to learn and gain new skills. The HR processes leveraged and integrated each of the HR practices. For instance, in the case of the communication processes, these were so closely bound up with training and development and job design that it was difficult to disaggregate them in the analysis. Similarly, teamwork was not simply a feature of job design but a mechanism for knowledge sharing, problem solving, developing new ideas, and training and development. The types of HR processes that were utilised resonate with the processes of enhancing knowledge and skills, sharing information and power, and rewarding performance that were first proposed in Lawler's (1986) work on highinvolvement practices.

In contrast, in the organisations using the productivity-based configuration, performanceoriented processes were used within each HR practice to maximise productivity but were not used to enhance integration between HR practices. As a result, each HR practice operated more or less as a stand-alone, intentionally focused practice that was used, in conjunction with specific targets, to monitor, control and sometimes punish particular aspects of employee behaviour. The HR processes in productivity-oriented organisations were used to deepen the impact of HR practices rather than to extend their impact as was the case in the organisations with commitment-oriented HR philosophies. The use of these practices and processes produced employee behaviours that were in keeping with the HR philosophy, and its focus on high productivity and efficiency. While this approach resulted in low morale, frustration with a lack of training and career opportunities, low levels of job satisfaction, and the inability to use skills on the part of employees, it also resulted in high productivity because those who did not reach the required targets simply lost their jobs.

\section{Employee interpretations of HR systems}

By focusing on employees' responses to two very different types of HR systems and by using qualitative data, we were able to go beyond mere descriptions of HR systems to provide a more nuanced understanding of how and why such systems work. First, we were able to shed light on why different HR configurations might be used in the management of a relatively homogeneous group of employees such as knowledge workers. Lepak and Snell (2002) were 
unable to provide explanations from their study as to why productivity approaches might be used in the management of knowledge workers when prior research suggests that such workers respond best to high-commitment HR systems (Collins and Smith, 2006). They surmised that there may be insufficient resources to invest in developing such employees, or that in 'particularly dynamic environments', such investment would not be recouped, or that there may be 'inertial pressures' that either 'encourage managers to use a productivity approach (or limit their freedom to adopt a commitment approach)' (p. 537). Our findings provide quite a different explanation. While the difficult economic environment had led some of the firms in the sample to focus on cost-cutting and efficiencies as a way of shoring up their businesses, those using a productivity-based HR configuration were simply exemplifying a deeply embedded philosophy about how people should be treated and managed (Schuler, 1992). This was then translated into HR practices and processes that reinforced this philosophy. The desired employee behaviour was productivity, and each of the practices and processes was designed with this in mind.

The two HR systems found in our research were characterised by very different HR philosophies and worked in different ways. At the same time, each system could be described as 'strong' on the basis that each resulted in what is regarded as the key determinant of a strong system: 'employees share a common interpretation of what is important and what behaviours are expected and rewarded' (Bowen and Ostroff, 2004: 204). Thus, each of the HR systems was designed for the 'specific organization objectives and needed role behaviours' that have been suggested as 'a promising way of conceptualising HRM' (Lepak and Shaw, 2008: 1490). The fact that many of the knowledge workers who were interviewed actively disliked the productivitybased HR systems does not necessarily negate their effectiveness; indeed, the processes in place to uphold the system - the withholding of salary increases or the loss of employment appeared to ensure that performance was achieved. The core principles of the system were embedded in the HR philosophies espoused by these firms, and these in turn were reinforced by core HR practices and processes. The various levels that exist within an HR system were, thus, interconnected (Becker and Gerhart, 1996), and the possibility of 'deadly connections' (Becker et al., 1997) reduced.

\section{LIMITATIONS}

The study is limited by the fact that it includes only seven firms and that we interviewed only a very small number of employees in each of these firms. In addition, we could only identify two specific types of HR system, and it is therefore possible that the role of HR philosophy and HR processes might be different in other types of system. Given the nature of our study, we had no objective performance data on which to base our assessment of outcomes, and we were reliant on employees' experiences of their work situations. Further research might focus on a wider range of organisations of different sizes and larger data sets that include interviews with a wider cross-section of knowledge workers, together with objective performance data.

\section{IMPLICATIONS FOR PRACTICE}

First, while a good deal of attention is paid by organisations and HR managers to the creation of successful HR strategies, far less attention has been given to the role that the HR philosophy may play in the overall design of an HR system. Similarly, while organisations busy themselves with the production of HR policies and the design of HR practices, they may pay limited attention to how these policies and practices are enacted through appropriate processes. Yet the 
research identified the important role of HR processes in the creation of synergies between HR practices (in the case of the commitment-oriented HR configuration), or in deepening and reinforcing the impact of the $\mathrm{HR}$ practices (in the case of the productivity-based HR configuration).

Second, job design was clearly a critical HR practice for all the knowledge workers who were interviewed, although whether this was viewed positively or negatively depended very much on the type of HR configuration used by the firm. Yet, while job design is generally included in the contents of standard HRM textbooks, it does not feature as a core HR practice but rather as a subsection of organisational design (e.g. Armstrong, 2009). In addition, job design does not feature as a topic listed on the Chartered Institute of Personnel and Development's UK section on 'HR Topics' on their website. Thus, it appears not to feature as a core HR issue, and it is therefore likely that HR managers have only limited expertise in this area. Our research suggests, however, that there is a need for an in-depth understanding of job design in the skill set of HR managers.

Finally, it is unclear whether the pursuit of the productivity-based, 'low road' HR approach to managing knowledge workers will enable such organisations to innovate and reinvent themselves if market conditions change within the ICT sector. In common with research into the UK software sector (Marks and Scholarios, 2007; Marks and Huzzard, 2010), we found a lack of investment in training and development for knowledge workers in firms that had used the productivity-based configuration. This was a cause of frustration to these staff, which may result in higher levels of turnover if economic conditions improve and new job opportunities emerge.

\section{CONCLUSIONS}

Our research, by focusing on the ways in which knowledge workers responded to two different HR systems, has provided some insights into the ways in which HR systems work. The research reveals the important role that HR philosophy and HR processes play in the working of HR systems, the choices that firms have in the ways in which they configure their HR systems, and the outcomes that may result.

\section{Acknowledgements}

This research is funded by the Irish Research Council for the Humanities and Social Sciences and the Economic and Social Research Council (RES-062-23-1183). The financial support of these institutions is gratefully acknowledged.

\section{REFERENCES}

Alvesson, M. (2001). 'Knowledge work: ambiguity, image and identity'. Human Relations, 54: 7 , 863-886.

Armstrong, M. (2009). Armstrong's Handbook of Human Resource Management Practice, London: Kogan Page.

Becker, B. and Gerhart, B. (1996). 'The impact of human resource management on organizational performance: progress and prospects'. Academy of Management Journal, 39: 4, 779-801.

Becker, B., Huselid, M., Pickus, P. and Spratt, M. (1997). 'HR as a source of shareholder value'. Human Resource Management, 36: 1, 389-447.

Boselie, P., Dietz, G. and Boon, C. (2005). 'Commonalities and contradictions in HRM and performance research'. Human Resource Management Journal, 15: 3, 67-94.

Bowen, D. and Ostroff, C. (2004). 'Understanding HRM-performance linkages: the role of the "strength" of the HR system'. Academy of Management Review, 29: 2, 203-221. 
Boxall, P., Ang, S. and Bartram, T. (2011). 'Analysing the "black box" of HRM: uncovering HR goals, mediators and outcomes in a standardized service environment'. Journal of Management Studies, 48: 7, 1504-1532.

Boxall, P. and Macky, K. (2009). 'Research and theory on high-performance work systems: progressing the high involvement stream'. Human Resource Management Journal, 19: 1, 3-23.

Chadwick, C. (2010). 'Theoretic insights on the nature of performance synergies in human resource systems: toward greater precision'. Human Resource Management Review, 20: 2, 85-101.

Choi, T.Y. and Varney, G.H. (1995). 'Rethinking the knowledge workers: where have all the workers gone?'. Organizational Development Journal, 13: 2, 41-50.

Collins, C. and Smith, K. (2006). 'Knowledge exchange and combination: the role of human resource practices in the performance of high-technology firms'. Academy of Management Journal, 49: 3, 544-560.

Department for Education and Skills (2005). Skills: Getting on in Business, Getting on in Work, Norwich: HMSO.

Expert Group on Future Skills Needs (EGFSN) (2008). Future Requirements for High Level ICT Skills in the ICT Sector, Dublin: EGFSN.

Godard, J. (2004). 'A critical assessment of the high-performance paradigm'. British Journal of Industrial Relations, 42: 2, 349-378.

Godard, J. and Delaney, J. (2000). 'Reflections on the "high performance" paradigm's implications for industrial relations as a field'. Industrial and Labor Relations Review, 53: 3, 482-502.

Guest, D.E. (2011). 'Human resource management and performance: still searching for some answers'. Human Resource Management Journal, 21: 1, 3-13.

Janz, B.D., Colquitt, J.A. and Noe, R.A. (1997). 'Knowledge worker team effectiveness: the role of autonomy, interdependence, team development, and contextual support variables'. Personnel Psychology, 50: 4, 877-904.

Jiang, K., Lepak, D., Han, K., Hong, Y., Kim, A. and Winkler, A.L. (2012). 'Clarifying the construct of human resource systems: relating human resource management to employee performance'. Human Resource Management Review, 22: 2, 73-85.

Kehoe, R. and Wright, P. (forthcoming). 'The impact of high performance human resource practices on employees' attitudes and behaviours'. Journal of Management, DOI: 10.1177/0123456789123456.

Kepes, S. and Delery, J. (2007). 'HRM systems and the problem of internal fit', in P. Boxall, J. Purcell and P. Wright (eds), The Oxford Handbook of Human Resource Management, Oxford: Oxford University Press.

Kinnie, N., Hutchinson, S., Purcell, J., Rayton, B. and Swart, J. (2005). 'Satisfaction with HR practices and commitment to the organisation: why one size does not fit all'. Human Resource Management Journal, 15: 4, 9-29.

Lawler, E. (1986). High Involvement Management, San Francisco, CA: Jossey-Bass.

Lepak, D. and Shaw, J. (2008). 'Strategic HRM in North America: looking to the future'. The International Journal of Human Resource Management, 19: 8, 1486-1499.

Lepak, D.P. and Snell, S.A. (1999). 'The human resource architecture: toward a theory of human capital allocation and development'. Academy of Management Review, 24: 1, 31-48.

Lepak, D.P. and Snell, S.A. (2002). 'Examining the human resource architecture: the relationships among human capital, employment and human resource configurations'. Journal of Management, 28: 4, 517-543.

Lepak, D., Taylor, M.S., Tekleab, A., Marrone, J. and Cohen, D. (2007). 'An examination of the use of high investment HR systems for core and support employees'. Human Resource Management, 46: 2, 223-246.

Macky, K. and Boxall, P. (2007). "The relationship between "high performance work practices" and employee attitudes: an investigation of additive and interaction effects'. International Journal of Human Resource Management, 18: 4, 537-567.

Marks, A. and Huzzard, T. (2010). 'Employability and the ICT worker: a study of employees in Scottish small businesses'. New Technology, Work and Employment, 25: 2, 167-181. 
Marks, A. and Scholarios, D. (2007). 'Revisiting technical workers: professional and organisational identities in the software industries'. New Technology, Work and Employment, 22: 2, 98-117.

Monks, K. and McMackin, J. (2001). 'Designing and aligning an HR system'. Human Resource Management Journal, 11: 2, 57-72.

Nishii, L., Lepak, D. and Schneider, B. (2008). 'Employee attributions of the "why" of HR practices; their effects on employee attitudes and behaviors and customer satisfaction'. Personnel Psychology, 61: 3, 503-545.

Orlitzky, M. and Frenkel, S.J. (2005). 'Alternative pathways to high performance workplaces'. International Journal of Human Resource Management, 16: 8, 1325-1348.

Osterman, P. (1995). 'Skill, training, and work organization in American establishments'. Industrial Relations, 34: 2, 125-146.

Pratt, M. (2009). 'For the lack of a boilerplate: tips on writing up (and reviewing) qualitative research'. Academy of Management Journal, 52: 5, 856-862.

Ramsay, H., Scholarios, D. and Harley, B. (2000). 'Employees and high performance work systems: testing inside the black box'. British Journal of Industrial Relations, 38: 4, 501-531.

Schuler, R. (1992). 'Strategic human resources management: linking the people with the strategic needs of the business'. Organizational Dynamics, 21: 1, 18-32.

Swart, J. and Kinnie, N. (2012). 'Managing multidimensional knowledge assets: HR configurations in professional service firms'. Human Resource Management Journal, DOI: 10.1111/j.17488583.2012.00197.x

Swart, J., Kinnie, N. and Purcell, J. (2003). People and Performance in Knowledge Intensive Firms, London: CIPD. 